\title{
A non-destructive method for estimating onion leaf area
}

\author{
J.I.Córcoles*, A. Domínguez, M.A. Moreno, J.F. Ortega and J.A. de Juan
}

Regional Center of Water Research. Castilla - La Mancha University. Carretera de las Peñas km 3,2. 02049, Albacete, Spain.

Abstract

Leaf area is one of the most important parameters for characterizing crop growth and development, and its measurement is useful for examining the effects of agronomic management on crop production. It is related to interception of radiation, photosynthesis, biomass accumulation, transpiration and gas exchange in crop canopies. Several direct and indirect methods have been developed for determining leaf area. The aim of this study is to develop an indirect method, based on the use of a mathematical model, to compute leaf area in an onion crop using non-destructive measurements with the condition that the model must be practical and useful as a Decision Support System tool to improve crop management. A field experiment was conducted in a 4.75 ha commercial onion plot irrigated with a centre pivot system in Aguas Nuevas (Albacete, Spain), during the 2010 irrigation season. To determine onion crop leaf area in the laboratory, the crop was sampled on four occasions between 15 June and 15 September. At each sampling event, eight experimental plots of $1 \mathrm{~m}^{2}$ were used and the leaf area for individual leaves was computed using two indirect methods, one based on the use of an automated infrared imaging system, LI-COR-3100C, and the other using a digital scanner EPSON GT-8000, obtaining several images that were processed using Image J v 1.43 software. A total of 1146 leaves were used. Before measuring the leaf area, 25 parameters related to leaf length and width were determined for each leaf. The combined application of principal components analysis and cluster analysis for grouping leaf parameters was used to reduce the number of variables from 25 to 12 . The parameter derived from the product of the total leaf length (L) and the leaf diameter at a distance of $25 \%$ of the total leaf length (A25) gave the best results for estimating leaf area using a simple Keywords linear regression model. The model obtained was useful for computing leaf area using a non-destructive method.

leaf area • onion • non-destructive method • mathematical model.

\section{Introduction}

Leaf area is one of the most important parameters for characterizing crop growth and development, and is useful for examining the effects of agronomic management on crop production (Hooker 1907; Azzi 1959; Gallagher and Biscoe 1978). This parameter is related to interception of radiation, photosynthesis, biomass accumulation, transpiration and gas exchange in crop canopies (Kucharik et al. 1998). It is also one of the most relevant parameters in experimentation, and has been used to predict harvest date (Hammer et al. 1995; Kiniry et al. 1996). Variables that are useful in agriculture and other disciplines, such as the leaf area index (LAI), which is defined as the total one-sided area of leaf tissue per unit ground surface area (Watson, 1947) are also computed from the leaf area. Accurate measurements of leaf area are essential for understanding the interaction between crop growth and environment (De Jesus et al. 2001).

Many methods of leaf area measurement have been developed for several crops (Gower et al. 1999; Kussner and Mosandl 2000; Jonckheere et al. 2004). Marshall (1968) classified methods to determine leaf area as direct and indirect. Direct methods measure all the leaves of the plant. These methods include the use of millimetric paper (Goodall 1947; Winter et al. 1956; Bachman and Keller 1965), planimetric (Daughtry 1990; Nyakwende et al. 1997) and gravimetric techniques (Frear 1935, Miller 1938) and tracing, blueprinting and photographing, which require instruments, tools and machines such as hand scanners and laser optic devices (Peksen 2007). An alternative method is the use of image analysis, either with a camera (Tarbell and Reid 1991; Baker et al. 1996) or an image scanner (Kershaw and Larsen 1992; Yonekawa et al. 1996), combined with digitalization of images. In these cases, the processing is time consuming and sometimes is suitable only for small plants with few leaves.

Indirect methods are useful when this equipment is not available or non-destructive measurements are needed, such as in field conditions or where there is low plant density. Regarding indirect methods, the solar radiation intercepted 
method (Gerdel and Salter 1928; Hibbard et al. 1937), automated infrared imaging system (Hatfield et al. 1985) or the estimation of leaf area based on linear measurements of the leaf (Ackley et al. 1958; Ray and Singh 1989; Astegiano et al. 2001) are the most common. Indirect methods enable researchers to measure leaf area on the same plants during the growth period and may reduce variability in experiments (Serdar and Demirsoy 2006). Considering all methods, the estimation method from mathematical models involving linear measurements of leaves (Coombs and Hall 1982; Beerling and Fry 1990) is relatively accurate. Measurements can be made without cutting the plants (Kvet and Marshall 1971). Simple and accurate models eliminate the need for expensive leaf area meters or time-consuming methods, as they are easy to apply and are non-destructive.

The aim of this study is to develop a mathematical model to compute leaf area in an onion crop using non-destructive leaf area measurements. This model should be applicable at different crop stages. The model must also be practical, to be used as a Decision Support System tool to improve crop management.

\section{Materials and methods}

\section{The case study}

The field experiment was conducted on a 4.75 ha commercial onion plot irrigated with a centre pivot system in Aguas Nuevas (Albacete, Spain), during the 2010 irrigation season. The study area was in warm Mediterranean climate (Papadakis 1966). The soil was classified as a Xeric Torriorthent with a loam texture, medium depth $(>600 \mathrm{~mm})$ and a composition of $4 \%$ coarse sand, $28 \%$ fine sand, $44 \%$ silt and $24 \%$ clay (USDA 2006). The area was characterised by a flat topography and soils had good drainage, with little sign of water erosion.

Onion seed (cultivar "Pandero") (Kumar et al. 2007; Sarkar et al. 2008; Enciso et al. 2009, Jiménez et al. 2010) was directly sown (27.7 plants $\mathrm{m}^{-2}$ ). Irrigation was scheduled using a simplified water balance method within the root area, following the Food and Agriculture Organization methodology (Pereira and Allen 1999). According to this methodology, the total amount of irrigation water applied was close to $4800 \mathrm{~m}^{3} \mathrm{ha}^{-1}$, with an average of the accumulated uniformity coefficient (CUac) close to $92 \%$. Data from an agrometeorological station (Campbell Scientific Inc., Logan, USA), located $300 \mathrm{~m}$ from the plot were used to obtain the 10-year average and the 2010 irrigation season weather data. Weed growth was controlled by pre-emergence treatment with pendimethalin (33\%) at a dose of $2 \mathrm{I} \mathrm{ha}^{-1}$. When the crop had between two and four leaves, a second treatment to control weeds was carried out with oxynil (22.5\%) at a dose of 1 I $\mathrm{ha}^{-1}$. Disease control was carried out with two treatments of mancozeb $(80 \%)$ at 100 and 115 days after sowing. The plot was fertilized with nitrogen ( $\left.230 \mathrm{~kg} \mathrm{~N} \mathrm{ha}^{-1}\right)$, phosphorous (220 $\left.\mathrm{kg} \mathrm{P}_{2} \mathrm{O}_{5} \mathrm{ha}^{-1}\right)$ and potassium (190 $\left.\mathrm{kg} \mathrm{K}_{2} \mathrm{O} \mathrm{ha}^{-1}\right)$.

\section{Sampling}

In order to determine onion crop leaf area in the laboratory during crop development (18 March to 22 September) the crop was sampled on four occasions between 15 June and 15 September. On each occasion, eight experimental sub-plots of $1 \mathrm{~m}^{2}$ were used, which were selected at random across the plot. Forty plants were collected throughout the plot on each sampling occasion. A total of 1146 leaves were measured across all the sampling occasions.

On each sampling occasion, the leaf area of individual leaves was computed using two indirect methods. The first method was based on the use of an automated infrared imaging system, LI-COR-3100C (LI-COR Inc., Lincoln, Nebraska, USA). The second method used a digital scanner EPSON GT8000 (Seiko Epson Corporation, Nagano, Japan), producing images that were processed using Image $\mathrm{J} v 1.43$ software.

Before measuring leaf area by the two indirect methods, 25 parameters were determined for each leaf (Table 1). Some of these parameters were previously used to determine the leaf area in onion crops (Hoffman 1971; Gamiely et al. 1991) and grapes (Legorburo 2005). Five of the parameters, defined as the main parameters, were measured directly with a tape measure ( $\pm 1 \mathrm{~mm}$ accuracy): total leaf length $(\mathrm{L})$, leaf width at base (A), leaf width from a distance of $25 \%$ (A25), $50 \%$ (A50) and $75 \%$ (A75) from leaf base. The remaining parameters (a total of 20) were computed using mathematical relationships of the main parameters. The computed parameters were associated with leaf size $(L \times A, L \times A 25, L \times A 50, L \times A 75, A \times A 25$, $A \times A 50, A \times A 75, A 25 \times A 50, A 25 \times A 75, A 50 \times A 75)$ and leaf shape (L/A, L/A25, L/A50, L/A75, A/A25, A/A50, A/A75, A25/ A50, A25/A75, A50/A75).

\section{Statistical analysis}

Statistical analyses were performed using SPSS software (SPSS, 2008). Descriptive statistics were calculated [average, standard deviation, minimum and maximum value, and coefficient of variation $(\mathrm{CV})$ ] to determine the variability of the measured and computed parameters.

Principal components analysis (PCA) was used to represent most of the variance among a large number of variables (in this case the parameters of each leaf) by a much smaller number of variables, termed factors (Pearson, 1902; Hotelling, 1933; Haan, 2002), which are linear combinations that maximize the shared portion of the variance. The objective of PCA is to obtain linear combinations of representative variables that exhibit maximum variance for a multidimensional 
Table 1. Description of the measured and the computed parameters determined for each leaf.

\begin{tabular}{|c|c|}
\hline Parameter & Description \\
\hline $\mathrm{L}(\mathrm{mm})$ & Total leaf length \\
\hline $\mathrm{A}(\mathrm{mm})$ & Leaf base width \\
\hline $\mathrm{A} 25(\mathrm{~mm})$ & Leaf width at a distance of $25 \%$ from the leaf base \\
\hline $\mathrm{A} 50(\mathrm{~mm})$ & Leaf width at a distance of $50 \%$ from the leaf base \\
\hline A75 (mm) & Leaf width at a distance of $100 \%$ from the leaf base \\
\hline$L \times A$ & $\mathrm{~L}$ and $\mathrm{A}$ product \\
\hline $\mathrm{L} \times \mathrm{A} 25$ & $\mathrm{~L}$ and $\mathrm{A} 25$ product \\
\hline $\mathrm{L} \times \mathrm{A} 50$ & $\mathrm{~L}$ and $\mathrm{A} 50$ product \\
\hline L×A75 & $\mathrm{L}$ and $\mathrm{A} 75$ product \\
\hline$A \times A 25$ & $\mathrm{~A}$ and $\mathrm{A} 25$ product \\
\hline $\mathrm{A} \times \mathrm{A} 50$ & A and $\mathrm{A} 50$ product \\
\hline $\mathrm{A} \times \mathrm{A} 75$ & $A$ and $A 75$ product \\
\hline $\mathrm{A} 25 \times \mathrm{A} 50$ & A25 and A50 product \\
\hline $\mathrm{A} 25 \times \mathrm{A} 75$ & A25 and A75 product \\
\hline $\mathrm{A} 50 \times \mathrm{A} 75$ & A50 and A75 product \\
\hline L/A & $L$ and $A$ ratio \\
\hline L/A25 & $\mathrm{L}$ and $\mathrm{A} 25$ ratio \\
\hline L/A50 & $\mathrm{L}$ and $\mathrm{A} 50$ ratio \\
\hline L/A75 & $\mathrm{L}$ and $\mathrm{A} 75$ ratio \\
\hline A/A25 & $A$ and $A 25$ ratio \\
\hline A/A50 & $A$ and $A 50$ ratio \\
\hline A/A75 & $A$ and $A 75$ ratio \\
\hline A25/A50 & $\mathrm{A} 25$ and $\mathrm{A} 50$ ratio \\
\hline A25/A75 & $\mathrm{A} 25$ and $\mathrm{A} 75$ ratio \\
\hline A50/A75 & $A 50$ and $A 75$ ratio \\
\hline
\end{tabular}

phenomenon and are also uncorrelated. Hence, it is possible to determine which parameters are more useful in explaining the leaf characteristics. The following steps were followed:

- Computation of the correlation matrix, to identify the most important correlation structures between leaf parameters and correlation coefficients. The correlation matrix was useful to explain the groups obtained in the next step, cluster analysis (CA) of the parameters.

- Computation of the percentage of variance explained. Thus, the selected factors were those representing a cumulative variance higher than $90 \%$.

- Computation of the rotated component matrix. Rotated loadings were determined for each factor using loading coefficients (Malinowski and Howery, 1980). Loading coefficients of the rotated matrix showed the participation of each leaf parameter in the formation of each factor.

A CA was then applied to the original group of variables to group parameters with similar characteristics thereby further reducing the number of parameters (Peña, 2000). An agglomerative hierarchical CA was applied to group parameters, and the similarity-dissimilarity measure was used for the correlation coefficient (Alhamed et al., 2002; Unal et al., 2003). Single linkage was used to link clusters, which is based on the shortest distance between objects.

The parameters selected using PCA and CA were used to obtain regression models between those parameters and leaf area. A general linear regression model (GLM) and several simple linear regression models were utilized (models 1 to 4 ).

\section{Model development}

Several models were tested. After confirming that the data met the assumptions of parametric statistical approaches, an analysis of regression residuals, by means of normality, homoscedasticity and independence test, was carried out to validate each model proposed. In addition, to compare the model predictions and the measurements, for each model, the goodness of fit was determined using the regression coefficient $\left(R^{2}\right)$ (Astegiano et al., 2001; Cittadini and Peri, 2006). The models used were:

Model 1: $\mathrm{y}=\mathrm{a} \mathrm{x}$; previously used to estimate leaf area in tomato (Lyon, 1948; Balakrishnan et al., 1992), cotton (Ashley et al., 1963), rice (Johnson, 1967; Palaniswamy and Gomez, 1974) and maize (McKee, 1964; Giovanardi, 1972).

Model 2: $y=a+c x$; previously used to estimate the leaf area of grapes (Manivel and Weaver, 1973; Smith and Kliewer, 1983; Elsner and Jubb, 1988), cucumber (Liebig, 1978; Robbins and Pharr, 1987), pepper (Ray and Singh, 1989), tomato (Astegiano et al., 2001) and onion (Gamiely et al., 1991).

Model 3: $\log y=a+c \log x ;$ previously used in grapes (Sepúlveda and Kliewer, 1983; Elsner and Jubb, 1988; Silvestre and Eiras-Dias, 2001), maize (Tarbell and Reid, 1991), and onion (Hoffman, 1971).

Model 4: logy= a logx; previously used by Legorburo (2005) to determine leaf area in grapes.

Statgraphics Plus ${ }^{\circledR}$ software (Llovet et al., 2000) and MatLab ${ }^{\circledR}$ functions were used for the PCA, CA, and regression models.

\section{Results}

\section{Climatic characteristics}

During the irrigation season, the coldest period was between November and March, with the lowest average temperature in December (Table 2). The hottest period was between June and 
August, with monthly average temperature close to $26^{\circ} \mathrm{C}$. The large difference between maximum and minimum temperature should be highlighted, with temperatures ranging from $37.6^{\circ} \mathrm{C}$ (July) and $-14.4^{\circ} \mathrm{C}$ (November). The climatic characteristics during the 2010 irrigation season were very similar to the 10 year average weather data (2000-2010) (Table 2).

The rainfall registered during the 2010 irrigation season was $0.1 \mathrm{~mm}$ (July) to $61.3 \mathrm{~mm}$ (December). Drought during July and August is the most important characteristic of the area.

\section{Descriptive statistical analysis}

The variability of the main parameters measured $(L, A$, A25, A50, and A75) on each sampling occasion is shown in Table 3. The variability of leaf area obtained using the automated infrared imaging system LI-COR-3100C, which showed similar results to the leaf area obtained using a digital scanner, is shown in Table 3.

For parameter $\mathrm{L}$, the $\mathrm{CV}$ values ranged from $28.76 \%$ (sampling occasion 3 ) to $38.01 \%$ (sampling occasion 1). The variability of parameter A was very similar to parameter L (27.99\% on sampling occasion 4 , and $32.76 \%$ on sampling occasion 2). For the other parameters measured (A25, A50, and A75), the highest variability was seen in A75, with CV from $27.19 \%$ (sampling occasion 1) to $61.02 \%$ (sampling occasion 2). The greatest variation was shown for AF (except in sampling occasion 2), reaching CV values of $47.4 \%$ (sampling occasion 2) to $61.34 \%$ (sampling occasion 1).

The correlation between the measured parameters of leaf size ( $L, A, A 25, A 50$, and $A 75)$ was not very strong. The strongest correlation occurred between $L$ and $A 25(r=$

Table 2. Climatic data of the area of this study for the 10-year average (from 2000-2010) and the 2010 irrigation season obtained from the agrometeorological station (Campbell Scientific Inc., Logan, USA).

\begin{tabular}{|c|c|c|c|c|c|c|}
\hline & \multicolumn{6}{|c|}{ 2000-2010 } \\
\hline & $\begin{array}{l}\text { Rainfall } \\
(\mathrm{mm})\end{array}$ & $\begin{array}{l}\text { Reference evapo- } \\
\text { transpiration (mm) }\end{array}$ & $\begin{array}{c}\text { Maximum tempera- } \\
\text { ture }\left({ }^{\circ} \mathrm{C}\right)\end{array}$ & $\begin{array}{c}\text { Minimum tempera- } \\
\text { ture }\left({ }^{\circ} \mathrm{C}\right)\end{array}$ & $\begin{array}{l}\text { Average tempera- } \\
\text { ture }\left({ }^{\circ} \mathrm{C}\right)\end{array}$ & Solar radiation $\left(\mathrm{MJ} \mathrm{m}^{-2}\right)$ \\
\hline January & 22.1 & 35.2 & 17.7 & -9.5 & 4.2 & 8.4 \\
\hline February & 24.0 & 49.0 & 18.8 & -7.0 & 5.4 & 11.6 \\
\hline March & 34.7 & 83.7 & 23.8 & -5.5 & 8.5 & 16.0 \\
\hline April & 49.7 & 107.3 & 26.5 & -0.8 & 11.5 & 20.6 \\
\hline May & 42.2 & 142.1 & 30.6 & 1.5 & 15.7 & 23.9 \\
\hline June & 26.2 & 190.4 & 35.8 & 6.4 & 21.4 & 27.0 \\
\hline July & 4.9 & 224.7 & 37.8 & 9.2 & 24.5 & 28.4 \\
\hline August & 9.1 & 194.6 & 37.7 & 8.6 & 23.8 & 24.6 \\
\hline September & 34.9 & 124.7 & 33.2 & 3.9 & 19.1 & 18.9 \\
\hline October & 47.3 & 76.4 & 28.6 & 0.7 & 14.1 & 13.1 \\
\hline November & 30.2 & 40.7 & 21.1 & -5.1 & 7.9 & 8.8 \\
\hline \multirow[t]{3}{*}{ December } & 26.2 & 29.4 & 16.4 & -8.0 & 4.7 & 7.4 \\
\hline & \multicolumn{6}{|c|}{2010} \\
\hline & $\begin{array}{l}\text { Rainfall } \\
(\mathrm{mm})\end{array}$ & $\begin{array}{l}\text { Reference evapo- } \\
\text { transpiration (mm) }\end{array}$ & $\begin{array}{l}\text { Maximum tempera- } \\
\text { ture }\left({ }^{\circ} \mathrm{C}\right)\end{array}$ & $\begin{array}{c}\text { Minimum tempera- } \\
\text { ture }\left({ }^{\circ} \mathrm{C}\right)\end{array}$ & $\begin{array}{l}\text { Average tempera- } \\
\text { ture }\left({ }^{\circ} \mathrm{C}\right)\end{array}$ & Solar radiation $\left(\mathrm{MJ} \mathrm{m}^{-2}\right)$ \\
\hline January & 48.8 & 29.3 & 16.1 & -11.0 & 4.7 & 6.7 \\
\hline February & 57.5 & 41.9 & 18.4 & -4.2 & 6.0 & 8.8 \\
\hline March & 49.3 & 75.3 & 20.7 & -6.0 & 7.7 & 14.7 \\
\hline April & 47.1 & 99.7 & 27.1 & -2.3 & 11.2 & 20.1 \\
\hline May & 33.5 & 135.3 & 31.1 & -0.9 & 13.6 & 24.2 \\
\hline June & 26.5 & 167.8 & 33.8 & 2.7 & 18.7 & 24.7 \\
\hline July & 0.5 & 240.2 & 37.6 & 12.1 & 25.7 & 28.4 \\
\hline August & 11.0 & 190.4 & 37.3 & 3.8 & 23.3 & 23.4 \\
\hline September & 28.2 & 123.3 & 32.8 & 2.8 & 18.0 & 19.3 \\
\hline October & 35.1 & 78.2 & 27.3 & -2.5 & 11.9 & 14.6 \\
\hline November & 29.5 & 35.9 & 20.0 & -14.4 & 4.6 & 9.0 \\
\hline December & 61.3 & 24.6 & 16.3 & -9.6 & 2.4 & 6.7 \\
\hline
\end{tabular}


Table 3. Descriptive statistics of the main leaf parameters measured on each sampling occasion.

\begin{tabular}{|c|c|c|c|c|c|c|}
\hline $07 / 21 / 2010$ & $\mathrm{~L}(\mathrm{~mm})$ & $A(\mathrm{~mm})$ & A25 (mm) & A $50(\mathrm{~mm})$ & A75 $(\mathrm{mm})$ & AF $\left(\mathrm{mm}^{2}\right)$ \\
\hline Average & 292.7 & 8.7 & 10.0 & 8.1 & 5.3 & 4195.0 \\
\hline Standard deviation & 111.3 & 2.7 & 3.4 & 4.0 & 1.4 & 2573.0 \\
\hline Minimum & 45.0 & 3.0 & 3.0 & 2.0 & 2.0 & 110.4 \\
\hline Maximum & 530.0 & 17.0 & 19.0 & 70.0 & 11.0 & 11120.0 \\
\hline Coefficient of variation (\%) & 38.03 & 30.95 & 33.86 & 49.65 & 27.20 & 61.33 \\
\hline $08 / 11 / 2010$ & $\mathrm{~L}(\mathrm{~mm})$ & $\mathrm{A}(\mathrm{mm})$ & A25 (mm) & A $50(\mathrm{~mm})$ & A75 (mm) & $\mathrm{AF}\left(\mathrm{mm}^{2}\right)$ \\
\hline Average & 328.7 & 10.7 & 12.7 & 9.9 & 6.4 & 6323.0 \\
\hline Standard deviation & 96.9 & 3.5 & 4.0 & 2.8 & 3.9 & 2997.0 \\
\hline Minimum & 45.0 & 3.0 & 3.0 & 3.0 & 1.0 & 214.6 \\
\hline Maximum & 500.0 & 25.0 & 22.0 & 18.0 & 70.0 & 13330.0 \\
\hline Coefficient of variation (\%) & 29.48 & 32.77 & 31.70 & 28.76 & 61.02 & 47.40 \\
\hline 09/01/2010 & $\mathrm{L}(\mathrm{mm})$ & $\mathrm{A}(\mathrm{mm})$ & A25 (mm) & A $50(\mathrm{~mm})$ & A75 (mm) & $\mathrm{AF}\left(\mathrm{mm}^{2}\right)$ \\
\hline Average & 360.4 & 10.9 & 13.8 & 11.3 & 6.9 & 6697.0 \\
\hline Standard deviation & 103.7 & 3.4 & 4.1 & 3.6 & 2.7 & 3215.0 \\
\hline Minimum & 70.0 & 3.0 & 3.0 & 2.0 & 1.0 & 527.0 \\
\hline Maximum & 650.0 & 26.0 & 25.0 & 22.0 & 17.0 & 15070.0 \\
\hline Coefficient of variation (\%) & 28.77 & 31.76 & 29.96 & 31.46 & 39.03 & 48.01 \\
\hline $09 / 15 / 2010$ & $\mathrm{~L}(\mathrm{~mm})$ & $\mathrm{A}(\mathrm{mm})$ & A25 (mm) & A $50(\mathrm{~mm})$ & A75 (mm) & $\mathrm{AF}\left(\mathrm{mm}^{2}\right)$ \\
\hline Average & 298.4 & 9.5 & 11.2 & 9.3 & 5.8 & 4310.0 \\
\hline Standard deviation & 111.8 & 2.7 & 3.4 & 2.9 & 1.9 & 2420.0 \\
\hline Minimum & 70.0 & 3.0 & 5.0 & 4.0 & 3.0 & 347.7 \\
\hline Maximum & 630.0 & 17.0 & 20.0 & 18.0 & 13.0 & 12220.0 \\
\hline Coefficient of variation (\%) & 37.47 & 27.99 & 30.04 & 31.33 & 32.52 & 56.15 \\
\hline All data sampling & $\mathrm{L}(\mathrm{mm})$ & $\mathrm{A}(\mathrm{mm})$ & A25 (mm) & A $50(\mathrm{~mm})$ & A75 (mm) & $\mathrm{AF}\left(\mathrm{mm}^{2}\right)$ \\
\hline Average & 321.6 & 9.9 & 11.9 & 9.6 & 6.1 & 5488.0 \\
\hline Standard deviation & 108.7 & 3.3 & 4.1 & 3.7 & 2.8 & 3077.0 \\
\hline Minimum & 45.0 & 3.0 & 3.0 & 2.0 & 1.0 & 110.4 \\
\hline Maximum & 650.0 & 26.0 & 25.0 & 70.0 & 70.0 & 15070.0 \\
\hline Coefficient of variation (\%) & 33.80 & 33.03 & 34.08 & 38.06 & 45.83 & 56.07 \\
\hline
\end{tabular}

0.71), $A$ and $A 25(r=0.77)$ and $A 25$ and $A 50(r=0.72)$. All of these correlations were highly significant $(p<0.001)$. The parameters $L$ and $A 25$ showed a strong correlation with leaf area, with coefficient values of 0.87 and 0.88 , respectively. Thus, these two parameters can be considered the most adequate to explain leaf area variability (Table 4).

\section{Principal component analysis}

In the correlation matrix (data not presented in the results) of the 26 parameters $(25$ measured and computed parameters and leaf area using LI-COR-3100C) used for PCA, the parameter leaf area had strong, positive correlations ( $r$ values of $0.8-0.9$ ) with the parameters $L, A 25, L \times A, L \times A 25, L \times A 50$, and $A \times A 25$. The parameters leaf area and $L \times A 25$ had the highest correlation coefficient values $(r=0.96)$. All of these correlations were highly significant $(p<0.001)$.

Strong correlations were also observed among the other parameters associated with leaf size $(L \times A, L \times A 25, L \times A 50$, $\mathrm{L} \times \mathrm{A} 75, \quad A \times A 25, \quad A \times A 50, \quad A \times A 75, \quad A 25 \times A 50, \quad A 25 \times A 75$, A50 $\times A 75)$. The most significant correlations were $A 25 \times A 75$ and $A 50 \times A 75(r=0.94), A \times A 75$ and $A 25 \times A 75(r=0.93)$, and $A$ and $A \times A 25(r=0.93)$.

The parameters associated with leaf shape (L/A, L/A25, L/ A50, L/A75, A/A25, A/A50, A/A75, A25/A50, A25/A75, A50/ 
Table 4. Correlation matrix between the main measured parameters of leaf size.

\begin{tabular}{|c|c|c|c|c|c|c|}
\hline Parameter & $\mathbf{L}$ & A & A25 & A50 & A75 & AF \\
\hline $\mathrm{L}$ & $1^{+*+*}$ & - & - & - & - & - \\
\hline A & $0.64^{* * *}$ & $1^{* *+}$ & - & - & - & - \\
\hline A25 & $0.71^{* * *+}$ & $0.77^{+*+*}$ & $1^{* *+}$ & - & - & - \\
\hline A50 & $0.48^{* * * *}$ & $0.53^{* * *+}$ & $0.72^{+* * *}$ & $1^{* *+*}$ & - & - \\
\hline A75 & $0.26^{* * *}$ & $0.32^{+* *+}$ & $0.45^{*+*}$ & $0.49^{*+* *}$ & $1^{m * *}$ & - \\
\hline $\mathrm{AF}$ & $0.87^{* * *}$ & $0.72^{+*+*}$ & $0.88^{* * *+}$ & $0.63^{* * * *}$ & $0.40^{*+*+}$ & $1^{\prime+*}$ \\
\hline
\end{tabular}

${ }^{* * *} p<0.001$

A75), had weaker correlations than the leaf size parameters (L, A, A25, A50, A75, L×A, L×A25, L×A50, L×A75, A×A25, $\mathrm{A} \times \mathrm{A} 50, \mathrm{~A} \times \mathrm{A} 75, \mathrm{~A} 25 \times \mathrm{A} 50, \mathrm{~A} 25 \times \mathrm{A} 75, \mathrm{~A} 50 \times \mathrm{A} 75$, leaf area) with correlation coefficients lower than 0.8 .

According to the PCA (Table 5), six factors were selected, because they represented a total cumulative variance of $96.17 \%$ and they had total eigenvalues greater than 1 (Legorburo, 2005). Factor 1 explained nearly half of the variance (close to $45.71 \%$ ) and the percentage of variance explained by factors 2, 3, 4, 5 and 6 was less important. The total cumulative variance explained by factors 1,2 and 3 was $77.42 \%$.

In Table 6, the loading coefficient of the rotated matrix for each one of the 26 parameters ( 25 measured and computed parameter and leaf area) utilized is shown. In factor 1 , the most relevant parameters were $L \times A, L \times A 25$ and $A \times A 25$; A75 was most relevant in factor 2 . In factors 3-6, the loading coefficient showed that L/A25, A/A25 and A25/A50 were most relevant.

\section{Cluster analysis}

Two clusters were formed, considering a similarity value close to 0.45 (Fig. 1). Cluster 1 was composed of parameters related to leaf size, which included measured $(L, A, A 25, A 50$, $A 75)$ and computed parameters (the products of $L \times A, L \times A 25$, $\mathrm{L} \times A 50, \mathrm{~L} \times \mathrm{A} 75, \mathrm{~A} \times \mathrm{A} 25, \mathrm{~A} \times \mathrm{A} 50, \mathrm{~A} \times \mathrm{A} 75, \mathrm{~A} 25 \times \mathrm{A} 50, \mathrm{~A} 25 \times \mathrm{A} 75$, A50 $\times A 75)$. Inside cluster 1 , two groupings have a similarity value close to 0.15 . The first grouping was composed of parameters $L \times A 25$, leaf area, $A 25, A, A \times A 25, A \times A 50$, $A 25 \times A 50, L \times A, A 50, L \times A 50$, and $L$. All of these parameters had a loading coefficient of the rotated matrix obtained in PCA higher than 0.6 in Factor 1 (Table 6). In the second grouping in Cluster 1, parameters $A 75, A \times A 75, A 25 \times A 75, A 50 \times A 75$ and $\mathrm{L} \times \mathrm{A} 75$ were included, all of which had a loading coefficient of the rotated matrix higher than 0.7 in Factor 2 (Table 6).

Cluster 2 was formed by the parameters related to leaf shape (L/A, L/A25, L/A50, L/A75, A25/A75, A/A75, A/A25, A/A50, $A 50 / A 75, A 25 / A 50)$. The level of similarity was lower than the similarity of parameters in cluster 1 . These parameters did not show high similarity with leaf area.

From the results of PCA and CA, the number of parameters
Table 5. Factors that maximize the shared portion of the variance obtained using the principal component analysis technique. Total and cumulative variance explained by each factor.

\begin{tabular}{lcc}
\hline & \multicolumn{2}{c}{ Initial eigenvalues } \\
\hline Factor & Total variance & \% Cumulative variance \\
\hline 1 & 11.88 & 45.71 \\
2 & 5.60 & 67.26 \\
3 & 2.64 & 77.42 \\
4 & 2.33 & 86.40 \\
5 & 1.50 & 92.16 \\
6 & 1.04 & 96.17 \\
7 & 0.33 & 97.43 \\
8 & 0.18 & 98.11 \\
. & $\cdot$ & $\cdot$ \\
. & $\cdot$ & $\cdot$ \\
. & $\cdot$ & $\cdot$ \\
26 & 0 & $\cdot$ \\
\hline
\end{tabular}

was reduced, considering the groupings obtained between parameters and the loading coefficients of the rotated matrix. Therefore, the initial number of parameters was reduced to 13, which included leaf area and the parameters related to leaf size ( $L, A, A 25, A 50, A 75, L \times A, L \times A 25, L \times A 50, L \times A 75$, $A \times A 50, A \times A 75, A 25 \times A 75)$.

\section{Regression models}

Regression models were determined using the 13 parameters selected from the PCA and CA. To use parameters collected using the non-destructive method, the leaf area was considered the dependent variable and the remaining 12 parameters as independent variables. To test the models, the measured leaf area of several plants on each sampling occasion was compared to the leaf area values obtained using the proposed models.

The first model used was a GLM using the 12 parameters (Table 7). A model using six independent variables was significant ( $L \times A, L \times A 25, L \times A 50, A \times A 50, A \times A 75, A 25 \times A 75)$ 


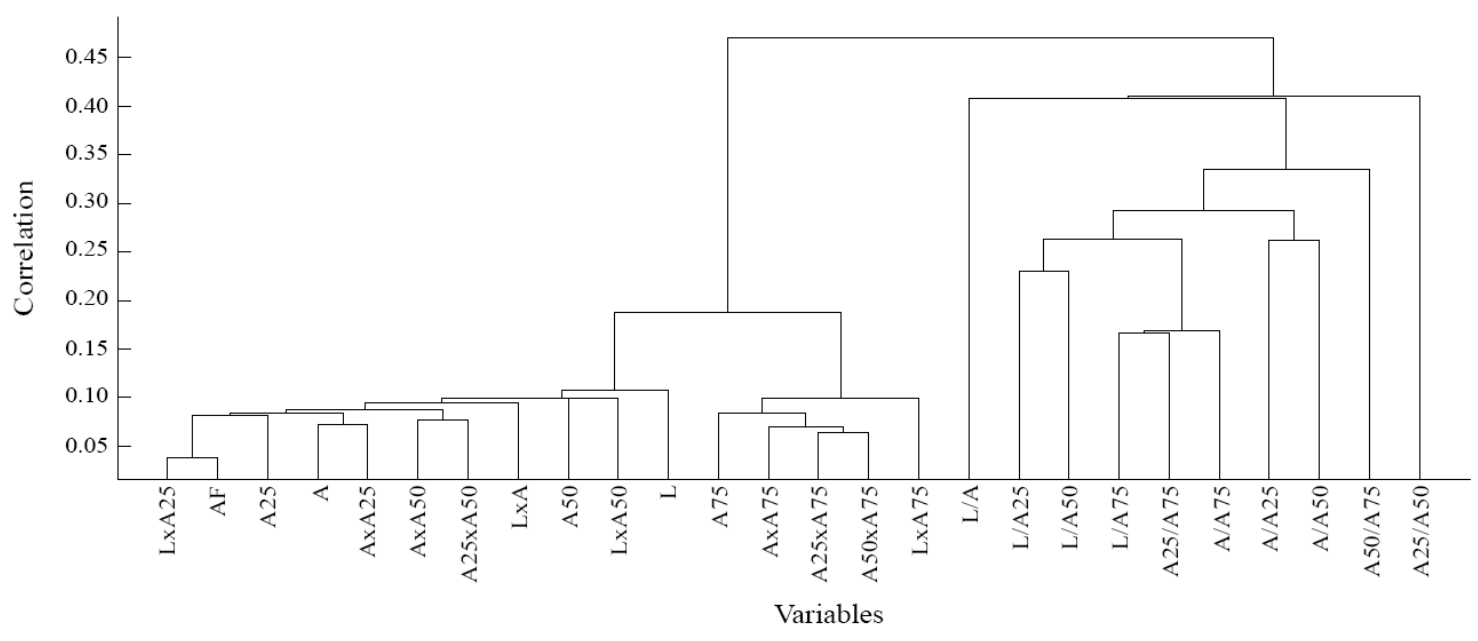

Figure 1. Dendrogram for agglomerative hierarchical cluster analysis using single linkage to group variables used.

Table 6. Loading coefficients of the rotated matrix obtained using the principal component analysis technique, which represent the participation of each leaf parameter in the formation of each factor.

\begin{tabular}{|c|c|c|c|c|c|c|}
\hline \multirow[b]{2}{*}{ Parameter } & \multicolumn{6}{|c|}{ Factor } \\
\hline & 1 & 2 & 3 & 4 & 5 & 6 \\
\hline$L$ & 0.787 & 0.119 & 0.562 & 0.103 & -0.075 & 0.111 \\
\hline A & 0.862 & 0.177 & -0.114 & 0.082 & 0.391 & 0.107 \\
\hline A25 & 0.886 & 0.280 & -0.116 & 0.117 & -0.220 & 0.173 \\
\hline A50 & 0.682 & 0.356 & -0.136 & 0.206 & -0.235 & -0.466 \\
\hline A75 & 0.236 & 0.923 & -0.038 & -0.234 & -0.098 & -0.069 \\
\hline$L \times A$ & 0.913 & 0.122 & 0.206 & 0.089 & 0.229 & 0.137 \\
\hline$L / A$ & 0.038 & 0.003 & 0.824 & 0.100 & -0.512 & 0.021 \\
\hline$L \times A 25$ & 0.917 & 0.185 & 0.184 & 0.097 & -0.164 & 0.175 \\
\hline L/A25 & -0.065 & -0.107 & 0.917 & 0.055 & 0.322 & -0.104 \\
\hline L×A50 & 0.869 & 0.268 & 0.186 & 0.143 & -0.203 & -0.219 \\
\hline L/A50 & 0.031 & -0.107 & 0.748 & 0.219 & 0.322 & 0.475 \\
\hline L×A75 & 0.574 & 0.732 & 0.241 & -0.168 & -0.126 & 0.009 \\
\hline L/A75 & 0.078 & -0.129 & 0.494 & 0.763 & 0.161 & 0.300 \\
\hline$A \times A 25$ & 0.916 & 0.220 & -0.200 & 0.096 & 0.104 & 0.158 \\
\hline A/A25 & -0.153 & -0.125 & 0.078 & -0.022 & 0.954 & -0.130 \\
\hline$A \times A 50$ & 0.868 & 0.312 & -0.220 & 0.145 & 0.076 & -0.206 \\
\hline A/A50 & 0.008 & -0.131 & 0.117 & 0.134 & 0.818 & 0.477 \\
\hline$A \times A 75$ & 0.622 & 0.722 & -0.153 & -0.147 & 0.126 & -0.005 \\
\hline A/A75 & 0.138 & -0.166 & 0.118 & 0.726 & 0.535 & 0.297 \\
\hline $\mathrm{A} 25 \times \mathrm{A} 50$ & 0.827 & 0.361 & -0.192 & 0.151 & -0.218 & -0.161 \\
\hline A25/A50 & 0.181 & -0.090 & 0.054 & 0.226 & 0.051 & 0.909 \\
\hline $\mathrm{A} 25 \times \mathrm{A} 75$ & 0.580 & 0.771 & -0.120 & -0.118 & -0.152 & 0.026 \\
\hline A25/A75 & 0.202 & -0.142 & 0.048 & 0.848 & -0.060 & 0.415 \\
\hline A50×A75 & 0.427 & 0.846 & -0.117 & -0.035 & -0.144 & -0.229 \\
\hline A50/A75 & 0.210 & -0.144 & -0.004 & 0.878 & -0.109 & -0.316 \\
\hline $\mathrm{AF}$ & 0.894 & 0.219 & 0.204 & 0.058 & -0.159 & 0.120 \\
\hline
\end{tabular}


and the other six parameters with significance levels greater than $5 \%$ were eliminated. The GLM explained $93.43 \%$ of leaf area variability (regression coefficient $\left(R^{2}\right)$ ), with a high level of significance $(p<0.01)$ and a standard error close to 7.888. The residuals fitted a normal distribution and showed homoscedastic behaviour. With regard to the GLM, the model overestimated the leaf area on all the sampling occasions analysed, with predicted leaf area values ranging from $10 \%$ (sampling occasion 2) to $20 \%$ (sampling occasion 4) higher than measured. Although the GLM explained a very high percentage of variance in the leaf area, the model included a lot of independent variables, which could make it difficult to use from a practical point of view.

In order to simplify the results, four simple regression models were examined. In each, one leaf area was considered the dependent variable, while the remaining parameters were

Table 7. Coefficients and standard error of the proposed general linear regression model using the six most significant independent variables

\begin{tabular}{lcc}
\hline Independent variable & Coefficients & Standard error \\
\hline & $-5.9610^{-5}$ & 0.525 \\
$\mathrm{~L} \times \mathrm{A}$ & -0.189 & 0.059 \\
$\mathrm{~L} \times \mathrm{A} 25$ & 1.234 & 0.053 \\
$\mathrm{~L} \times \mathrm{A} 50$ & 0.384 & 0.040 \\
$\mathrm{~A} \times \mathrm{A} 50$ & -7.486 & 1.057 \\
$\mathrm{~A} \times \mathrm{A} 75$ & 28.126 & 3.805 \\
$\mathrm{~A} 25 \times \mathrm{A} 75$ & -15.464 & 2.828 \\
\hline
\end{tabular}

taken individually as independent variables.

For model 1 , the highest regression coefficient $\left(R^{2}\right)$ value (close to $92.43 \%$ ) and minimum model standard error (8.46) were obtained using parameter L×A25 as the independent variable (Table 8 ). The dispersion pattern of residuals did not follow a normal distribution and showed heteroscedastic behaviour. Model 1 results were different depending on sampling occasion. Hence, on sampling occasion 1 (21/7) and $3(9 / 1)$, the model tended to overestimate the leaf area, giving predicted leaf area values $15 \%$ higher than those measured. In the case of sampling $2(8 / 11)$, this model underestimated leaf area, with predicted values $10 \%$ less than measured. For the last sampling occasion (9/15), the leaf area obtained with model 1 showed high divergence, with predicted leaf area values obtained approximately $25 \%$ higher than measured.

Model 2 was a logarithmic transformation for the dependent and independent variables (Table 9). Considering parameters $L \times A$ or $L \times A 50$, the regression coefficient $\left(R^{2}\right)$ reached values close to $90 \%$ and higher, for example with the parameter LXA25 (93.08\%). The dispersion pattern of residuals did not follow a normal distribution and showed heteroscedastic behaviour. For model 2, the results obtained were slightly different compared with model.1 In most cases analysed (sampling occasion 1, 2 and 3), this model underestimated the leaf area, with predicted leaf area AF values $30 \%$ less than measured. On sampling occasion 4 (9/15), predicted leaf areas were approximately $40 \%$ less than measured.

In comparison to the other models, model 3 gave the best results for estimating leaf area (Fig. 2), with regression coefficient $\left(R^{2}\right)$ values that were greater for most of the

Table 8. Goodness of fit of the simple regression model $1(y=a x)$ proposed to estimate the leaf area (y) depending on the independent variable utilized (x). Analysis of regression residuals (normality, homoscedasticity and independence test).

\begin{tabular}{|c|c|c|c|c|c|c|}
\hline $\begin{array}{l}\text { Independent } \\
\text { variable }\end{array}$ & $\mathbf{R}^{2}$ & Standard error & a & Independence & Normal distribution & Homoscedastic \\
\hline L & 69.73 & 0.001690 & 0.0178 & NO & NO & NO \\
\hline A & 50.82 & 0.002157 & 0.5658 & NO & NO & NO \\
\hline A25 & 70.67 & 0.001666 & 0.4826 & NO & NO & NO \\
\hline A50 & 39.96 & 0.002384 & 0.5659 & NO & NO & NO \\
\hline A75 & 2.28 & 0.003041 & 0.8181 & NO & NO & NO \\
\hline$L \times A$ & 75.04 & 0.001537 & 1.5604 & NO & NO & NO \\
\hline $\mathrm{L} \times \mathrm{A} 25$ & 92.43 & 0.000846 & 1.3141 & YES & NO & NO \\
\hline L×A50 & 79.17 & 0.001404 & 1.6419 & YES & NO & YES \\
\hline $\mathrm{L} \times \mathrm{A} 75$ & 49.35 & 0.002189 & 2.4805 & YES & NO & YES \\
\hline$A \times A 50$ & 50.09 & 0.002173 & 50.019 & YES & NO & NO \\
\hline$A \times A 75$ & 28.59 & 0.002600 & 77.030 & YES & NO & YES \\
\hline $\mathrm{A} 25 \times \mathrm{A} 75$ & 30.56 & 0.002564 & 61.698 & YES & NO & YES \\
\hline
\end{tabular}


Table 9. Goodness of fit of the simple regression model 2 (log $y=a \log x)$ proposed to estimate the leaf area (y) depending on the independent variable utilized (x). Analysis of regression residuals (normality, homoscedasticity and independence test).

\begin{tabular}{|c|c|c|c|c|c|c|}
\hline $\begin{array}{l}\text { Independent } \\
\text { variable }\end{array}$ & $\mathbf{R}^{2}$ & Standard error & a & Independence & Normal distribution & Homoscedastic \\
\hline L & 10.80 & 0.517 & 4.162 & NO & NO & NO \\
\hline A & 51.71 & 0.248 & 1.169 & NO & NO & NO \\
\hline A25 & 69.66 & 0.196 & 1.215 & NO & NO & NO \\
\hline A50 & 55.63 & 0.238 & 1.159 & NO & NO & NO \\
\hline A75 & 31.43 & 0.295 & 1.054 & NO & NO & NO \\
\hline$L \times A$ & 85.26 & 0.137 & 0.927 & NO & NO & NO \\
\hline $\mathrm{L} \times \mathrm{A} 25$ & 93.08 & 0.093 & 0.954 & YES & NO & NO \\
\hline L×A50 & 88.73 & 0.119 & 0.921 & NO & NO & NO \\
\hline$L \times A 75$ & 77.91 & 0.167 & 0.855 & NO & NO & NO \\
\hline $\mathrm{A} \times \mathrm{A} 50$ & 57.80 & 0.232 & 0.582 & NO & NO & NO \\
\hline$A \times A 75$ & 46.95 & 0.260 & 0.555 & NO & NO & NO \\
\hline A25×A75 & 54.59 & 0.240 & 0.565 & NO & NO & NO \\
\hline
\end{tabular}

parameters considered (Table 10). The best result was obtained using parameter $L \times A 25$, although the variability explained by the model did not improve more than in models 1 and 2. The model selected, leaf area $=0.000199+1.277$ $\mathrm{L} \times \mathrm{A} 25$, explained $92.53 \%$ of the variability of leaf area, and the dispersion pattern of the residuals followed a normal distribution and showed homoscedastic behaviour. Moreover, the model showed good results when used on each sampling occasion. On sampling occasion 1 and 3, predicted leaf area using this model was $8 \%$ higher than measured. For sampling occasion 2 and 4, the model underestimated the leaf area, with predicted values approximately $6 \%$ less than measured. The variability explained for some parameters by model 4 (Table 11) was slightly higher than in the other models considered. The highest regression coefficient $\left(R^{2}\right)$ value reached was for parameter $L \times A 25$ (93.45\%), although the dispersion pattern of residuals did not follow a normal distribution and showed heteroscedastic behaviour. Model 4 tended to overestimate leaf area values in all the sampling occasions. Hence, predicted values were close to $28 \%$ (sampling occasion 1 and 3), 12\% (sampling occasion 3) and $14 \%$ (sampling occasion 4 ) higher than measured.

\section{Discussion}

All measured parameters showed high variability on each sampling occasion. This is explained by the intrinsic heterogeneous size of leaves on each onion plant and also by the variability of plant size between the different sampling

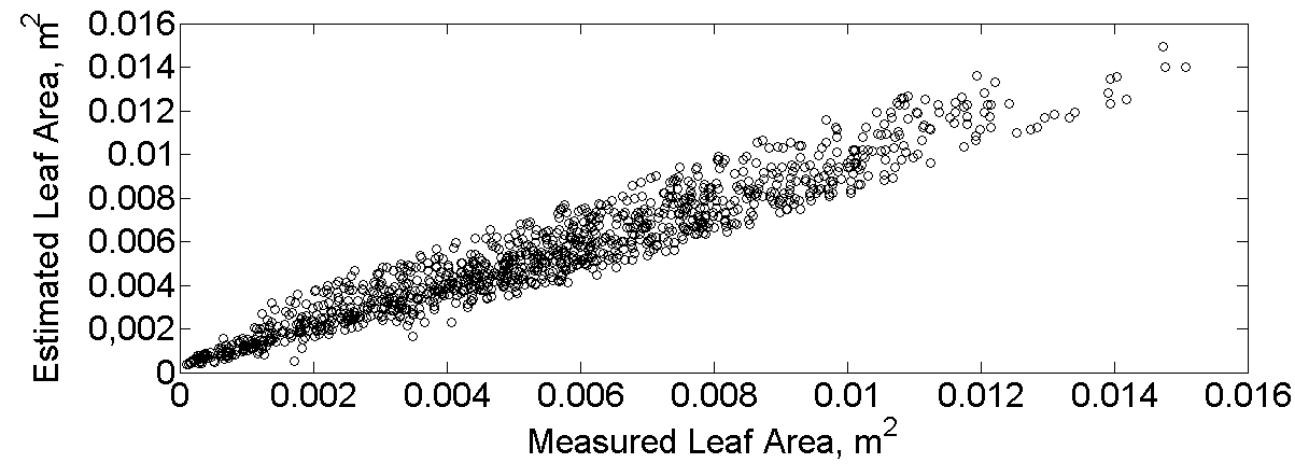

Figure 2. Relationship between the measured leaf area and the estimated leaf area using the linear model selected (leaf area = $0.000199+1.277 L \times A 25)$. 
Table 10. Goodness of fit of the simple regression model $3(y=a+c x)$ proposed to estimate the leaf area (y) depending on the independent variable utilized (x). Analysis of regression residuals (normality, homoscedasticity and independence test).

\begin{tabular}{|c|c|c|c|c|c|c|c|}
\hline Independent variable & $\mathbf{R}^{2}$ & Standard error & a & c & Independence & Normal distribution & Homoscedastic \\
\hline $\mathrm{L}$ & 76.28 & 0.001498 & -0.002464 & 0.024730 & NO & NO & NO \\
\hline A & 52.46 & 0.002122 & -0.001259 & 0.680298 & NO & NO & NO \\
\hline A25 & 77.24 & 0.001468 & -0.00244 & 0.666715 & YES & NO & NO \\
\hline A50 & 40.14 & 0.002381 & 0.000366 & 0.532653 & NO & NO & NO \\
\hline A75 & 16.29 & 0.002815 & 0.002771 & 0.443820 & NO & NO & NO \\
\hline$L \times A$ & 76.12 & 0.001503 & 0.001503 & 1.41210 & YES & NO & YES \\
\hline $\mathrm{L} \times \mathrm{A} 25$ & 92.53 & 0.000840 & 0.000199 & 1.27743 & YES & YES & YES \\
\hline $\mathrm{L} \times \mathrm{A} 50$ & 79.59 & 0.001390 & 0.000427 & 1.54129 & YES & NO & YES \\
\hline L×A75 & 56.10 & 0.002038 & 0.001578 & 1.90872 & NO & NO & NO \\
\hline$A \times A 50$ & 56.58 & 0.002027 & 0.002027 & 38.6951 & NO & NO & NO \\
\hline$A \times A 75$ & 42.71 & 0.002342 & 0.002342 & 51.8716 & NO & NO & NO \\
\hline A25×A75 & 46.70 & 0.002246 & 0.002246 & 41.3314 & NO & NO & NO \\
\hline
\end{tabular}

Table 11. Goodness of fit of the simple regression model $4(\log y=a+c \log x)$ proposed to estimate the leaf area (y) depending on the independent variable utilized (x). Analysis of regression residuals (normality, homoscedasticity and independence test).

\begin{tabular}{|c|c|c|c|c|c|c|c|}
\hline Independent variable & $\mathbf{R}^{2}$ & Standard error & a & c & Independence & Normal distribution & Homoscedastic \\
\hline L & 85.66 & 0.135 & -1.457 & 1.720 & YES & NO & NO \\
\hline A & 60.16 & 0.225 & 1.427 & 1.869 & NO & NO & NO \\
\hline A25 & 80.55 & 0.157 & 1.384 & 1.919 & YES & NO & NO \\
\hline A50 & 62.41 & 0.219 & 1.168 & 1.726 & NO & NO & NO \\
\hline A75 & 32.04 & 0.294 & 0.400 & 1.232 & NO & NO & NO \\
\hline$L \times A$ & 86.55 & 0.131 & 0.333 & 1.055 & YES & NO & NO \\
\hline $\mathrm{L} \times \mathrm{A} 25$ & 93.45 & 0.091 & 0.161 & 1.018 & YES & NO & NO \\
\hline L×A50 & 90.07 & 0.112 & 0.332 & 1.048 & YES & NO & NO \\
\hline L×A75 & 81.21 & 0.154 & 0.603 & 1.071 & YES & NO & NO \\
\hline$A \times A 50$ & 72.82 & 0.186 & 1.978 & 1.065 & NO & NO & NO \\
\hline$A \times A 75$ & 59.10 & 0.228 & 1.972 & 1.015 & NO & NO & NO \\
\hline $\mathrm{A} 25 \times \mathrm{A} 75$ & 66.39 & 0.207 & 1.733 & 0.976 & NO & NO & NO \\
\hline
\end{tabular}

dates as plants got older as the year progressed.

During the irrigation season, it should be highlighted that the growing conditions were not influenced by external factors, such as extreme climatic conditions or water stress, among others. In fact, the farm work and crop operations followed the traditions of the farmers in the area (De Juan et al., 2003), and the crop was maintained free of diseases and weeds.
The crop growing stages, which were monitored using the phenological scale proposed by Feller et al. (1995), showed that plants were growing as expected at each stage. In this experimental study, the onset of bulbing occurred at 75 days after emergence (DAE). Leaves continued to expand thereafter until $110 \mathrm{DAE}$ (bulbing stage), when the maximum LAI was reached. The highest LAI values were close to 1.72 
$\mathrm{m}^{2}$ leaf $\mathrm{m}^{-2}$ soil. After the maximum LAI was reached, the following stage lasted around 20 days (until 130 DAE) as the LAI values decreased rapidly in the last stage, when the leaves started to die. At the end, LAl values were close to $0.50 \mathrm{~m}^{-2}$ leaf $\mathrm{m}^{-2}$ soil. These LAI values were very similar to the values obtained by Tei et al (1996), who explained that the cessation of appearance of new leaf blades occurs with the onset of bulbing.

Model 3 was very similar to the model obtained for an onion crop by Gamiely et al. (1991), and the authors selected a model " $y=a+c x$ ", considering total leaf length $(L)$ as the independent variable. Other authors such as Hoffman (1971), developed a model "log $y=a+c \log x$ " also using $L$ as the independent variable.

In all the proposed models, sampling occasion 4 showed the highest differences between predicted and measured leaf area, which can be explained by most of plants being at the leaf senescence stage.

It is expected that the models proposed in this paper can be used in other areas where growing conditions are normal. In situations with restriction of water or fertilizer application, or crops with diseases and weeds, the use of these models is not recommended.

Linear regression models that use leaf length and width are the most commonly used models and parameters for determining leaf area in several crops. Cittadini and Peri (2006) estimated leaf area using leaf length and width for sweet cherry. In this case, linear regression equations were fit using the length, width and their product as independent variables. Olfati et al. (2009) obtained leaf area estimates of red cabbage based on predictive equations derived from linear measurements of leaf length and width and their combination. A linear equation with width as the independent variable provided the most accurate estimate of leaf area in this study. In different Pecan cultivars, Torri et al. (2009) used regression linear models to determine leaf area, using the length and width as independent variables.

The use of non-linear regression models is less extensive for estimating leaf area. Thus, Antunes et al. (2008) used non-destructive measurements of leaf length and width for estimating the area of leaves of eight field-grown coffee cultivars. In this case, they obtained better results using power models than linear models.

Using mathematical models for estimating the leaf area would be an easy and time efficient non-destructive method for users. This approach could be useful for managers in agriculture and can be regarded as a decision support system tool since it can help in monitoring crop growth, while providing information for farmers on crop growth and development, water demand or biomass production. Such a mathematical model for estimating the leaf area reduces sampling effort and cost, and may increase precision where samples of leaf size are difficult to handle.

The use of these models is difficult to introduce in agriculture, due to the low technical knowledge of some producers. In spite of this, most of water users associations are advised by technicians, who would make the introduction of these tools easier. Moreover, several decision support system tools, such as irrigation advisory services, are now working in irrigable areas, so the use of these models might be included as a complementary activity of the irrigation advisory services, helping producers to use them.

\section{Conclusions}

The combined application of multivariate techniques such as PCA and CA for grouping leaf parameters was useful in reducing the number of variables from 25 to 12 . Among the mathematical models proposed in this paper, the GLM explained a high proportion of high leaf area variability and fulfilled the model assumptions of normal distribution and homoscedasticity. The simple linear regression model " $y$ $=a+c x$ " yielded very similar results to those obtained with the GLM. Thus, both models were useful non-destructive methods for estimating leaf area. Model 3 ("leaf area = $0.000199+1.277 \mathrm{~L} \times \mathrm{A} 25$ ") was the best predictor of the leaf area. The use of mathematical models to estimate the leaf area is a non-destructive, easy and time efficient method for calculating the leaf area. It may be useful for farm managers and farmers, and can be regarded as a decision support system tool since it could be used to monitor crop growth and provide information to farmers on crop growth and development, water demand, weed control, and biomass production, among others.

\section{Acknowledgements}

We would like to thank to the CICYT for funding the national project (AGL2007-66716-CO3-03), and the Education Regional Government of C-LM for funding the project (PCI080117). We also wish to thank Aisco Equipment Europe, Ltd. and the Agro-environmental Training Centre ("Centro de Formación Agroambiental") in Albacete for their support of this work, through providing the products and facilities needed to carry out this experiment. 
Ackley, W.B., Crandall, P.C. and Rusell, T.S. 1958. The use of linear measurements in estimating leaf areas. Proceedings of the American Society for Horticultural Science 72: 326-330.

Alhamed, A. Lakshmivarahan, S. and Stensrund, D.J. 2002. Cluster analysis of multimodel ensemble data from SAMEX. Monthly Weather Review 130: 226-256.

Antunes, W.C., Pompelli, M.F., Carretero, D.M. and DaMatta, F.M. 2008. Allometric models for non-destructive leaf area estimation in coffee. Annals of Applied Biology 153:33-40.

Ashley, D.A., Doss, B.D. and Bennet, O.L. 1963. A method for determining leaf area in cotton. Agronomy Journal 55: 584-585.

Astegiano, E.D., Favaro, J.C. and Bouzo, C.A. 2001. Estimación del área foliar en distintos cultivares de tomate utilizando medidas lineares foliares. Investigación Agraria Producción y Protección Vegetal 16: 249-256.

Azzi, G. 1959. Ecología Agraria. Ed. Salvat, S.A. Madrid, España.

Bachman, P. and Keller, B. 1965. Messeinrichtung zur Bestimmung von Blattoberflächen. Schweiz Forswes 116: 623-625.

Baker, B., Olszyk, D.M. and Tingey, D. 1996. Digital image analysis to estimate leaf area. Journal of Plant Phisiology 148: 530-535.

Balakrishnan, K., Sundaram, K.M., Ajunan, A. and Matarajatnam, N.A. 1992. A simple method for estimating leaf area in tomato. Madras Agricultural Journal 79: 162-163.

Beerling, D.J. and Fry, J.C. 1990. A comparison of the accuracy, variability and speed of five different methods for estimating leaf area. Annals of Botany 65: 483-488.

Cittadini, E.D. and Peri, P.L. 2006. Estimation of leaf area in sweet cherry using a non-destructive method. Instituto Nacional de Tecnología Agropecuaria 35: 143-150.

Coombs, J. and Hall, D.O. 1982. Whole Plant Photosynthesis and Productivity. In: "Techniques in Bioproductivity and Photosynthesis" (ed. J. Coombs, D.O. Hall, and S.P. Long), Pergamon Press, Oxford, pages 171-184.

Daughtry, C. 1990. Direct measurements of canopy structure. Remote Sensing Reviews 5: 45-60.

De Jesus, W.C., Do Vale, F.X.R., Coelho, R.R. and Costa, L.C. 2001. Comparison of two methods for estimating leaf area index on common bean. Agronomy Journal 93: 989-991.

De Juan, J. A., Ortega, J. F. and Tarjuelo, J. M. 2003. "Sistemas de cultivo. Evaluación de itinerarios técnicos". Mundi Prensa, Madrid, España, 830 pages.

Elsner, E.A. and Jubb, G.L. 1988. Leaf area estimation of Concord grape leaves from simple linear measurements. American Journal of Enology and Viticulture 39: 95-97.

Enciso, J., Wiendenfeld, B., Jifon, J. and Nelson, S. 2009. Onion yield and quality response to two irrigation scheduling strategies. Scientia Horticulturae 120: 301-305.

Frear, D.H.1935 Photolelectric apparatus for measuring leaf areas. Journal of Plant Phisiology 10: 69-574.
Gallagher, J.N. and Biscoe, R.V. 1978. Radiation, absorption, growth and yield of cereals. Journal of Agronomy and Crop Science 91: 47-60.

Gamiely, S., Randle, W.M., Mills, H.A. and Smittle, D.A. 1991. A rapid and non-destructive method for estimating leaf area of onions. Hortscience 26: 206.

Gerdel, R.W. and Saltter, R.M. 1928. Measurement of leaf area using the photoelectric cell. American Society of Agronomy 20: 635-642.

Giovanardi, R. 1972. Stima dell'area fogliare mediante misru biometriche ed applicazioni allo studio della dinamica di accrescimento del mais. Italian Journal of Agronomy 6: 243-247.

Goodall, D.W. 1947. Diurnal changes in the area of cacao leaves. Annals of Botany 11: 449-451.

Gower, S.T., Kucharik, C.J. and Norman, J.M. 1999. Direct and indirect estimation of leaf area index, fAPAR, and net primary production of terrestrial ecosystems. Remote Sensing of Environment 70: 29-51.

Haan, C.T. 2002. "Statistical Methods in Hydrology". lowa State University Press, IO, USA, 378 pages.

Hammer, G.L., Sinclair, T.R., Boote, K.J., Wright, G.C., Meinke, H. and Bell, M. 1995. A peanut simulation model. I Model development and testing. Agronomy Journal 87: 1085-1093.

Hatfield, J.L., Kanemasu, E.T., Asrar, G., Jackson, R.D., Pinter, P.J., Reginato, R.J. and Idso, S.B. 1985. Leaf area estimates from spectral measurements over various planting dates of wheat. Intern. Journal of Remote Sensing 6: 167-175.

Hibbard, R.P., Grisby, B.H. and Keck, W.G. 1937. A low light intensity photoelectric device for the measuring of leaf areas. Papers of the Michigan Academy of Science 23: 141-147.

Hoffman, G.J. 1971. Estimating leaf area from length measurements for hybrid granex onion. Agronomy Journal 63: 948-949.

Hooker, R. H. 1907. Correlation of the weather and crops. Journal of the Statistical Society 70: 1-51.

Hotelling, H. 1933. Analysis of a complex of statistical variables into principal components. Journal of Educational Psychology 24: 417-441.

Jiménez, M., de Juan, J.A., Tarjuelo, J.M. and Ortega, J.F. 2010. Effect of irrigation uniformity on evapotranspiration and onion yield. Journal of Agricultural Science 148: 139-157.

Johnson, R.E. 1967. Comparison of methods for estimating cotton leaf area. Agronomy Journal 59: 493-494.

Jonckheere, I., Fleck, S., Nackaerts, K., Muys, B., Coppin, P., Weiss, M. and Baret, F. 2004. Review of methods for in situ leaf area index determination: Part I. Theories, sensors and hemispherical photography. Agricultural and Forest Meteorology 121: 19-35.

Kershaw, J.H. and Larsen, D.R. 1992. A rapid technique for recording and measuring the leaf area of conifer needle samples. Tree Physiology 11: 411-417.

Kiniry, J.R., Sanderson, M.A., Williams, J.R., Tischler, C.R., Hussey, M.A., Ocumpaugh, W.R., Read, J.C., Esbroeck, G. and Reed, R.L. 
1996. Simulation Alamo, switchgrass with the ALMANAC model. Agronomy Journal 88: 607-613.

Kucharik, C.J., Norman, J.M. and Gower, S.T. 1998. Measurements of branch area and adjusting leaf area index to indirect measurements. Agricultural and Forest Meteorology 91: 69-88.

Kumar, S., Imtiyaz, M., Kumar, A. and Singh, R. 2007. Response of onion (Allium cepa L.) to different levels of irrigation water. Agricultural Water Management 89: 161-166.

Kussner, R. and Mosandl, R. 2000. Comparison of direct and indirect estimation of leaf area index in mature Norway spruce stands of eastern Germany. Canadian Journal of Forest Research 30: 440-447.

Kvet, J. and Marshall, J.K. 1971. Assessment of leaf area and other assimilating plant surfaces. In: "Methods of Studing Photosynthetic Production of Plants" (ed. Z. Sestak and J. Catsky), Junk Publishers, The Netherdlands, pages 315-331.

Legorburo, A. 2005. Estimación del área foliar en Vitis vinifera L. Tesis Doctoral. Escuela Técnica Superior de Ingenieros Agrónomos, Universidad de Castilla La Mancha, Albacete, España

Liebig, H.P. 1978. Einflüsse endogner und exogener faktoren auf die ertragsbildung von salatgurken unter besondener berücksichtigung von ertragsrhytmik, bestandesdichte and schnittmabnahmen. Dissertation, University of Hannover, Hannover, Germany.

Llovet, J., Delgado, D. and Martínez, J. 2000. Statgraphics Plus 4. Guía Práctica para Usuarios. Anaya Multimedia S.A., Madrid, España.

Lyon, C.J. 1948. A factor method for the area of tomato leaves. Journal of Plant Physiology 23: 634-635.

Malinowski, E.R., and Howery, D.G., 1980. "Factor Analysis in Chemistry". Wiley-InterScience, New York, USA, 251 pages

Manivel, L. and Weaver, R.J. 1973. Biometric correlation between leaf area and length measurements of Grenache grape leaves. Hortscience 9: 27-28.

Marshall, J.K. 1968. Methods for leaf area measurement of large and small samples. Photosynthetica 2: 41-47.

McKee, G.W. 1964. A coefficient for computing leaf area in hybrid corn. Agronomy Journal 56: 240-241.

Miller, E.C. 1938. "Plant Physiology". McGraw-Hill Co, New York, USA, 1201 pages.

Nyakwende, E., Paull, C.J. and Atherton, J.G. 1997. Non - destructive determination of leaf area in tomato plants using image processing. Journal of Horticultural Science 72: 255-262.

Olfati, J.A., Peyvast, G., Sanavi, M., Slaehi, M. Mahdipour, M. and Nosratie-Rad, Z. 2009. Comparison of leaf area estimation from linear measurements of Red Cabbage. International Journal of Vegetables Science 15: 185-192.

Palaniswamy, K.M. and Gomez, K.A. 1974. Length-width method for estimatin leaf area of rice. Agronomy Journal 66: 430-433.

Papadakis, J. 1966. "Climates of the World and Their Agricultural Potentialities". Hemisferio Sur, Buenos Aires, Argentina, 174 pages.

Pearson, K. 1902. On lines and planes of closest fit to systems of points in space. Philosophical Magazine 2: 559-572.

Peksen, E. 2007. Non-destructive leaf area estimation model for faba bean (Vicia faba L.). Scientia Horticulturae 113: 322-328.

Peña, D. 2000. "Estadística: Modelos y métodos 2. Modelos lineales y series temporales”. Alianza Editorial S.A. Madrid, España, 550 páginas.

Pereira, L. S. and Allen, R. G. 1999. Crop water requirements. In: "CIGR Handbook of Agricultural Engineering, Vol. I: Land and Water Engineering, Chapter 5: Irrigation and Drainage" (ed. H.N. van Lier, L.S. Pereira and F.R. Steiner), St. Joseph, MI, USA, pages 213-262.

Ray, R.C. and Singh, R.P. 1989. Leaf area estimation in capsicum. Scientia Horticulturae 39: 181-188.

Robbins, N.S. and Pharr, D.M. 1987. Leaf area prediction models for cucumber from linear measurements. Hortscience 22: 12641266.

Sarkar, S., Goswami, S.B., Mallick, S. and Nanda, M.K. 2008. Different indices to characterize water use pattern of micro-sprinkler irrigated onion (Allium cepa L.). Agricultural Water Management 95: 625-632.

Sepúlveda, G. and Kliewer, M. 1983. Estimation of leaf area of two grapevine cultivars using laminae linear measurements and fresh weight. American Journal of Enology and Viticulture 4: 221-226.

Serdar, U. and Demirsoy, H. 2006. Non-destructive leaf area estimation in chestnut. Scientia Horticulturae 108: 227-230.

Silvestre, J. and Eiras-Dias, J.E. 2001. Allometric relationship between leaf area and length measurements of Vitis vinifera $\mathrm{L}$. leaves. Ciencia e Técnica Vitivinicola 16: 35-42.

Smith, R. and Kliewer, W.M. 1983. Estimation of Thompson Seedless grapevine leaf area. American Journal of Enology and Viticulture 35: 16-22.

SPSS, 2008. "SPSS ${ }^{2} 16.0$ Brief Guide". SPSS Inc, Chicago, USA, 653 pages.

Tarbell, K.A. and Reid, J.F. 1991. A computer vision system for characterizing corn growth and development. Transactions of the ASAE 34: 2245-2255.

Tei, F., Scaife, A. and Aikman, P. 1996. Growth of lettuce, onion, and red beet. 1. Growth analysis, light interception, and radiation use efficiency. Annals of Botany 78: 633-643.

Torri, S.I., Descalzi, C. and Frusso, E. 2009. Estimation of leaf area in Pecan cultivars. Ciencia e Investigacion Agraria 36: 53-58.

Unal, Y., Kindap, T. and Karaca, M. 2003. Redefining the climate zones of Turkey using cluster analysis. International Journal of Climatology 23: 1045-1055.

USDA, 2006. "Keys to Soil Taxonomy, 10th ed". United States Department of Agriculture, Natural Resources Conservation Services, Washington D.C., USA, 339 pages.

Watson, D.J. 1947. Comparative physiological studies in the growth of field crops. Variation in net assimilation rate and leaf area between species and varieties, and within and between years. Annals of Botany 11: 41-76. 
Winter, E.J., Salter, P.J., Stanhill, G. and Bleasdale, J.K. 1956. Some methods of measuring leaf area. In: "The growth of leaves" (ed. F.L. Milthorpe), Butterworths Scientific publications, London, England.
Yonekawa, S., Sakai, N. and Kitani, O. 1996. Identification of idealized leaf types using simple dimensionless shape factors by image analysis. Transaction of the ASAE 39: 1525-1533. 